\title{
Body composition in Prader-Willi syndrome compared with nonsyndromal obesity: Relationship to physical activity and growth hormone function
}

\author{
Edgar G. A. H. van Mil, MD, PhD, Klaas R. Westerterp, PbD, Willem-Jan M. Gerver, MD, PbD, \\ Wouter D. Van Marken Lichtenbelt, PhD, Arnold D. M. Kester, PhD, and Wim H. M. Saris, MD, PhD
}

\begin{abstract}
Objective: To study the relationship of fat mass, extracellular-to-intracellularwater ratio, and bone mineral density with growth hormone function and physical activity in Prader-Willi syndrome.

Study design: There were 17 patients with PWS (10 women, ages 7.5-19.8 years) and 17 obese control patients, matched for gender and bone age. FM and extracellular-to-intracellular-water ratio were measured by bromidedeuterium dilution, BMD by dual-energy x-ray absorptiometry, GH function by fasted serum insulin-like growth factor-I concentration, and physical activity by doubly-labeled water in combination with basal metabolic rate by a ventilated hood.
\end{abstract}

Results: The PWS group had a similar fat mass, but a lower fat-free mass, whereas the extracellular-to-intracellular-water ratio was higher compared with the control group $(0.87 \pm 0.07 \mathrm{l} / \mathrm{l}$ and $0.80 \pm 0.06 \mathrm{l} / \mathrm{l}$, respectively $[P<$ $.01])$. Fat mass was inversely related with PA in the PWS group, whereas IGF-I was positively correlated with FFM, ICW, and BMD of the limbs. BMD tended to be lower in patients with PWS.

Conclusions: In children and adolescents with PWS, adiposity is associated with a reduced fat-free mass and extracellular-to-intracellular-water ratio is increased. Both findings are related to GH function and physical activity. BMD, especially in the limbs, tends to be reduced in patients with PWS and is related to GH function. ( $\mathrm{J}$ Pediatr 2001;139:708-14)

Prader-Willi syndrome ${ }^{1}$ is known as a syndrome of hypotonia, hypogonadism, mental retardation, and obesity and is a complex genetic disorder that results from the absence of normally active paternally inherited genes at chromosome 15(q11-13). ${ }^{2}$ Despite early interventions, obesity is still one of the major

From the Departments of Human Biology, Pediatrics, and Methodology es Statistics, The Nutrition Toxicology and Environment Research Institute Maastricht (NUTRIM), The Netherlands.

Submitted for publication Dec 13, 1999; revisions received Jan 16, 2001, and June 5, 2001; accepted July 2, 2001.

Reprint requests: Edgar G. A. H. van Mil, MD, PhD, Departments of Human Biology and Pediatrics, Maastricht University, PO Box 616 Maastricht, 6200 MD, the Netherlands.

Copyright $(9) 2001$ by Mosby, Inc.

$0022-3476 / 2001 / \$ 35.00+0 \quad 9 / 21 / 118399$

doi: $10.1067 / \mathrm{mpd} .2001 .118399$ 
are less active than nonsyndromal children. ${ }^{11}$ Although the inverse relationship between obesity and activity has been established in nonsyndromal or primary obesity, ${ }^{12-14}$ it is unclear whether this relationship also exists in secondary obesity, such as PWS. The hypothesis was that activity and GH function would have an inverse relationship with adiposity in patients with PWS. Furthermore, it was hypothesized that the ECW/ICW ratio would be inversely related to GH function, indicating a functional GHD in children with PWS.

The aim of the present study, therefore, was to measure fat mass, body water compartments, and bone mineralization in patients with PWS compared with control patients with nonsyndromal obesity matched for gender and bone age, and to associate these body composition parameters with GH function and physical activity in patients with PWS.

\section{Methods}

\section{Patients}

Patients ( $\mathrm{n}=17$, ages $7.5-19.8$ years) were recruited with the assistance of the Dutch Prader-Willi Association. The patients were assessed according to the Holm criteria, ${ }^{3}$ which provides a quantitative measure of PWS symptoms. PWS was preferably confirmed by either a deletion on chromosome 15 or uniparental disomy. When only clinical data were available, critical evaluation took place by the same clinical geneticist. The patients with PWS were gender- and bone-age-matched with nonsyndromal obese control patients (ages 6.3-15.3 years) recruited from the regional public health department. Bone age measurement, a means of assessing the rate of maturational change throughout the growing period, provides an estimate of biological maturation, and therefore, is a better matching criterion than calendar age. ${ }^{15}$ Bone age was determined by assessing epiphyseal maturation by the same pediatric endocrinologist with the use of a radi- ograph of the midportion of the left hand and standard growth data. ${ }^{16}$ None of the patients with PWS were receiving hormone therapy or treatment with human GH before or during the study. Control patients with endocrine causes or other secondary causes of obesity were excluded from this study (Table I). All patients were measured in the summer months to avoid the potential confounding factor of seasonal variation in activity. ${ }^{17}$

Before the start of the study, parents gave written informed consent that was further confirmed with an oral approval by the child. The study was approved by the medical ethics committee of Maastricht University, the Netherlands.

\section{General Outline of Protocol}

Total energy expenditure or average daily metabolic rate and total body water were measured according to the Maastricht Protocol for the measurement of body composition and energy expenditure with labeled water. The Maastricht protocol is based on measurements of stable isotopes in the urine, after the patient has received an orally administered stable isotope mixture. The protocol has been previously described in detail. ${ }^{18-20}$ Total body weight was measured on an electronic scale (E1200, Mettler Instumente AG, Greifensee, Switzerland) in the morning before the patients consumed any food or drink, after voiding, and while wearing underclothing. The heights of the patients without shoes was measured by using a stadiometer. Furthermore, a total body scan was made with a dual energy x-ray absorptiometer (DPX-L, Lunar Corp, Madison, Wis).

\section{Basal Metabolic Rate}

The basal metabolic rate measurement was started after the patients had lain supine for 10 minutes. Oxygen consumption and carbon dioxide production were measured for 40 to 50 minutes by use of a computerized, open circuit ventilated hood system as the patient watched television. ${ }^{19,20}$

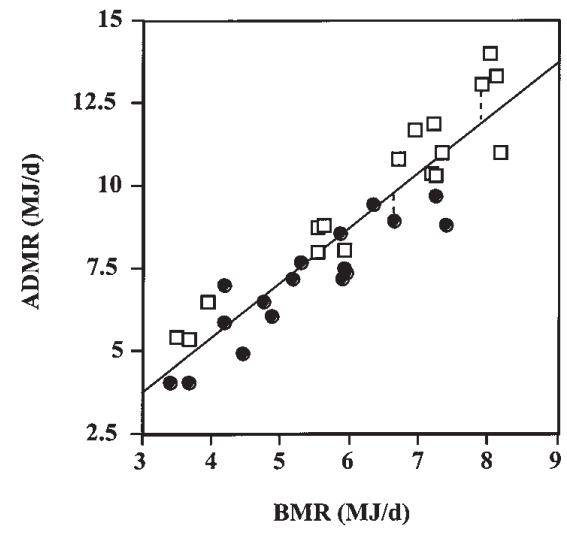

Fig 1. Activity-related energy expenditure. $A D M R$, in $M J / d$, as a function of $B M R$, in $M J / d$, plotted for the group with PWS (filled circles) and control group (open squares). The dotted lines represent examples of the residual of the regression for a specific patient, which is a relative measure of activity-related energy expenditure.

MJ/d, Megajoules per day.

\section{ADMR and Activity by Doubly-labeled Water}

The isotope disappearance rates in the urine from the samples of days 1,8 , and 14 were used to calculate carbon dioxide production, which was converted to ADMR with a respiratory exchange ratio equal to the food quotient derived from a 1-week food diary calculated by a dietician. The total observed variance in ADMR, plotted as a function of BMR, can be subdivided into 2 components, one that is attributable to the regression with BMR and one that is not attributable to this regression, the residual of the regression. The residual of each patient represents the variance in PA-related energy expenditure and can be used as a relative measure of PA. Activity-related energy expenditure was, therefore, defined as the residual from the regression of ADMR with BMR (rADMR) (Fig 1). This measure was chosen instead of the PA index (ADMR/BMR), because of the nonzero intercept in the regression of AMDR with BMR. The use of ADMR/BMR may lead to a misinterpretation of the PA level in the younger patients with lower values of BMR. ${ }^{21,22}$ 
Table I. Patient characteristics (shown as mean \pm SD)

$\begin{array}{lcc} & \text { PWS }\left(\mathrm{n}_{1}=17\right) & \text { Control }\left(\mathrm{n}_{2}=17\right) \\ \text { Gender }(\mathrm{F}: \mathrm{M}) & 10: 7 & 10: 7 \\ \text { Bone age }(\mathrm{y}) & 12.7 \pm 2.9 & 12.7 \pm 3.2 \\ \text { Age }(\mathrm{y}) & 11.9 \pm 3.4 & 11.3 \pm 2.6 \\ \text { Tanner }(1-5) & 2.6 \pm 1.6 & 2.6 \pm 1.7 \\ \text { Height }(\mathrm{m}) & 1.43 \pm 0.16 & 1.49 \pm 0.20 \\ \text { Weight }(\mathrm{kg}) & 50.0 \pm 19.7 & 61.5 \pm 25.6 \\ \text { BMI }\left(\mathrm{kg} / \mathrm{m}^{2}\right) & 23.5 \pm 6.0 & 26.0\end{array}$

\section{Body Composition by Deuterium Dilution}

Fat-free mass was assessed with the assumption of FFM containing TBW, which was calculated from isotope abundance in the urine, as the ${ }^{2} \mathrm{H}$ dilution space divided by 1.04 , correcting for exchange of the ${ }^{2} \mathrm{H}$ label with nonaqueous $\mathrm{H}$ of body solids. ${ }^{23}$ Hydration factors of FFM were figured on the basis of gender- and maturation-specific values. ${ }^{24}$ Maturation was assessed according to Tanner's puberty ratings. ${ }^{25}$ With the use of a 2-compartment model, FM was calculated by subtracting FFM from the patient's total body weight and also expressed as a percentage of the patient's total body weight $(\% \mathrm{FM})$. To allow for comparisons between patients, FM and FFM were expressed as an index, FFMI $\left(\mathrm{kg} / \mathrm{m}^{2}\right)$ and FMI $\left(\mathrm{kg} / \mathrm{m}^{2}\right)$, respectively. Patients with PWS have a typical pattern of growth, such as a stunting in growth during adolescence $^{26,27}$ that leads to changes in agerelated body composition. In this way, we have corrected for the large variation in height, analogous with BMI, where $\mathrm{BMI}=\mathrm{FFMI}+\mathrm{FMI}^{28}$

\section{Extracellular Water}

TBW can be divided into ICW and ECW. The ECW compartment was determined by bromide dilution, and the bromide concentration was determined from serum after a 10 -hour fast. Corrected bromide space was calculated according to the method of Miller et al. ${ }^{29}$ ICW is calculated by subtracting ECW from TBW.

\section{Bone Mineral Content, Bone Mineral Density, and Percentage of $F M$ by $D X A$}

Total bone mineral content and total bone mineral density were measured on the same day by DXA with the use of a pediatric scan mode. BMC was measured as total mass and calculated as a percentage of FFM as determined by DXA. BMD and BMC were calculated separately for the limbs $\left(\mathrm{BMD}_{\text {limbs' }}\right.$ $\left.\mathrm{BMC}_{\text {limbs }}\right)$. All DXA measurements were calculated by Lunar software (version $1.5 \mathrm{~g}$, Lunar Corp, Madison, Wis). Furthermore, \%FM was calculated as an alternative measurement to be compared with \%FM provided by the deuterium dilution method.

\section{Measurement of Serum Insulin-like Growth Factor-I}

The serum insulin-like growth factor-I concentration was measured by using a commercially available assay (RIA, Nichols Institute Diagnostics, San Juan Capistrano, Calif). IGF-I was determined only in the group with PWS by a measurement performed in serum taken from a fasted venous blood sample.

\section{Statistical Analysis}

Differences between the independent variables of the group with PWS and the obese control group were analyzed by the 2 -sample $t$ test. A multiple-linearregression model, with FMI as the dependent variable and FFMI as the independent variable, was used to analyze the difference in FMI between the
PWS and control groups, defined by the binary variable PWS status. In this analysis, FMI is a function of FFMI. The difference of the influence of FFMI on FMI in regression slope was tested by using an interactive variable of PWS status and FFMI, after correction for FFMI in the equation. Consequently, the difference between groups, corrected for FFMI, was estimated and tested for significance by using linear regression and assuming equal slopes. The same procedure was followed for ECW/ICW as the dependent variable, and bone age, FMI, gender, PWS status, and rADMR as independent variables were used to analyze the difference between both groups, adjusted for the independent variables.

Specifically for the group with PWS, the partial correlation coefficients of IGF-I and ECW/ICW, and of IGF-I and ICW, adjusted for bone age and FMI, were calculated. In addition, the correlation coefficients of IGF-I and FM, and of IGF-I and FFM, adjusted for bone age, were assessed. Third, the partial correlation coefficients of IGF-I and measures of bone mineralization, adjusted for bone age and body weight, were calculated. The significance level was chosen at $5 \%$. Data were expressed as mean \pm SD. SPSS release 6.1 for Macintosh (SPSS Inc, Chicago, Ill) was used as the statistical package.

\section{Results}

Age, height, weight, and BMI of the patients of the PWS and obese control groups were not significantly different (Table I). Sexual maturation in both groups ranged from pre- to postpubescent.

FFM and FFMI were lower in the group with PWS, whereas FM, \%FM, and FMI values were not significantly different. However, when FMI was expressed as a function of FFMI, the regression slopes were similar and the group difference was significant, as was evident from multiple regression. TBW, 


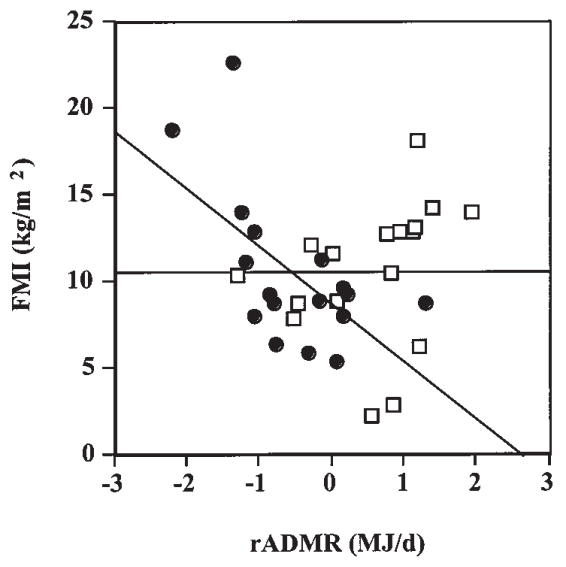

Fig 2. Comparison of FMI with activity. FMI, in $\mathrm{kg} / \mathrm{m}^{2}$, as a function of activity-related energy expenditure ( $r A D M R$, in $M J / d$ ) plotted for the group with PWS (filled circles) and the control group (open squares). The regression line of the control patients was not significant. The dotted line represents the mean $\mathrm{FMl}$ of the control group. The regression equation for PWS: $\mathrm{FMI}=-3.30 \mathrm{rADMR}+8.75\left(r^{2}=0.36\right.$; $P<.05)$.

$M J / d$, Megajoules per day.

measured by deuterium dilution technique, was significantly lower in the group with PWS. ECW and ICW were lower; however, ECW/ICW was higher in the group with PWS. Because of difficulties we had in obtaining blood samples, ECW values were not obtained in 1 patient with PWS and 1 patient in the control group (Table II). \%FM measured by DXA was comparable with $\%$ FM measured by deuterium dilution (PWS, $43.7 \pm 7.9 \%$ and $44.9 \pm 8.9 \%$; control, $39.1 \pm 8.8 \%$, and $40.2 \pm 12.1 \%$, respectively; Pearson's correlation, 0.95 $(P<.0001)$.

$\mathrm{BMC}$, expressed as a percentage of FFM, was higher in the group with PWS; however, the other measurements of bone mineralization, though not significant, tended to be lower in the group with PWS, especially for the limbs (Table II).

The mean IGF-I level for the group with PWS was $151.8( \pm 94.7) \mathrm{ng} / \mathrm{mL}$, which is within the low to normal range. IGF-I adjusted for bone age showed a positive correlation with FFM $(P<.05)$. There was no significant correlation between IGF-I and

Table II. Body composition results by deuteriumbromide dilution technique and DXA of patients with PWS and obese control patients*

\begin{tabular}{|c|c|c|}
\hline & PWS $\left(n_{1}=17\right)$ & Control $\left(n_{2}=17\right)$ \\
\hline FFM (kg) & $27.5 \pm 9.9 \ddagger$ & $35.9 \pm 13.4$ \\
\hline FFMI $\left(\mathrm{kg} / \mathrm{m}^{2}\right)$ & $12.9 \pm 2.3 \S$ & $15.4 \pm 2.7$ \\
\hline FM (kg) & $22.4 \pm 11.7$ & $25.6 \pm 12.7$ \\
\hline FMI $\left(\mathrm{kg} / \mathrm{m}^{2}\right)$ & $10.6 \pm 4.5$ & $10.6 \pm 4.0$ \\
\hline TBW (L) & $20.5 \pm 7.1 \ddagger$ & $26.7 \pm 9.8$ \\
\hline $\mathrm{ECW}(\mathrm{L}) \dagger$ & $9.6 \pm 3.3 \ddagger$ & $12.3 \pm 4.1$ \\
\hline $\mathrm{ECW} / \mathrm{ICW}+$ & $0.87 \pm 0.07 \S$ & $0.80 \pm 0.06$ \\
\hline TBMC (g) & $1564 \pm 590$ & $1897 \pm 803$ \\
\hline $\mathrm{BMC}_{\text {limbs }}(\mathrm{g})$ & $315 \pm 143$ & $439 \pm 216$ \\
\hline TBMC $_{\% \mathrm{FFM}}(\%)$ & $6.0 \pm 0.7 \ddagger$ & $5.2 \pm 1.1$ \\
\hline $\operatorname{TBMD}\left(\mathrm{g} / \mathrm{cm}^{2}\right)$ & $1.005 \pm 0.126$ & $1.036 \pm 0.152$ \\
\hline $\mathrm{BMD}_{\text {limbs }}\left(\mathrm{g} / \mathrm{cm}^{2}\right)$ & $0.832 \pm 0.157$ & $0.888 \pm 0.181$ \\
\hline \multicolumn{3}{|c|}{$\begin{array}{l}\text { Mean } \pm \mathrm{SD} \text {. } \\
\dagger \mathrm{n}_{1}=\mathrm{n}_{2}=16 \\
\text { Significantly different from control group (Independent-samples } t \text { test): } \\
¥ P<.05 \text {. } \\
\$ P<.01 .\end{array}$} \\
\hline
\end{tabular}

$\mathrm{ECW} / \mathrm{ICW}$ when corrected for bone age and FMI, whereas for ICW, the partial correlation coefficient of IGF-I was significant $(P<.01)$. IGF-I adjusted for bone age and body weight was positively correlated with $\mathrm{BMD}_{\text {limbs }}$ (Table III).

There was no correlation between rADMR and $\mathrm{BMD}_{\text {limbs }}$. FMI, plotted as a function of rADMR, resulted in an inverse relation, but only for the patients with PWS, not for the control patients (Fig 2).

The increased ECW/ICW in the group with PWS was confirmed by multiple regression, correcting for bone age, FMI, gender, and PA. By using this model, other significant determinants in explaining the variance in ECW/ICW, besides PWS status, were bone age and FMI.

\section{Discussion}

Previous reports have shown a combination of increased FM and reduced FFM in patients with PWS. ${ }^{30,31}$ The present results demonstrate that adiposity in patients with PWS is characterized by an underdevelopment of FFM and not excessive growth of FM. The absolute and relative measures of fat mass (FM, FMI, and \%FM) were similar, whereas FFM in absolute value and corrected for height (FFMI) was significantly lower in the group with PWS. Moreover, multiple regression demonstrated that if FMI was plotted as a function of FFMI, the linear regression line through the PWS group was drawn parallel with, though underneath, the line of the control group. The use of indices for FFM and FM, which correct for height, offer a comparison in body composition on the basis mainly of body weight, analogous with BMI, and they are especially valuable in children with a typical pattern of growth, like patients with PWS. ${ }^{26,27}$ With these indices, it now becomes clear that the low FFM in patients with PWS is the reason that adiposity levels between groups can be similar, despite the tendency of an average higher BMI in the control group. BMI underestimates the adiposity in patients with PWS and is not the appropriate measure for those patients' comparison with nonsyndromal patients. The underdevelopment of FFM as the basis for adiposity in PWS might be caused by a functional GHD, as supported by the positive rela- 
Table III. Partial correlation coefficients of IGF-I and body composition parameters in patients with PWS

\begin{tabular}{|c|c|c|}
\hline Variable & Partial correlation & $\begin{array}{c}\text { Partial correlation } \\
\text { coefficient }\end{array}$ \\
\hline FM & IGF-I, adjusted for bone age & -0.31 \\
\hline FFM & IGF-I, adjusted for bone age & $0.60 *$ \\
\hline $\mathrm{ECW} / \mathrm{ICW}$ & IGF-I, adjusted for bone age and FMI & 0.06 \\
\hline ICW & IGF-I, adjusted for bone age and FMI & $0.77 \dagger$ \\
\hline TBMD & IGF-I, adjusted for bone age and body weight & 0.37 \\
\hline $\mathrm{BMD}_{\text {limbs }}$ & IGF-I, adjusted for bone age and body weight & $0.63 \%$ \\
\hline
\end{tabular}

tionship between IGF-I and FFM, adjusted for bone age.

Although the effect of PA on FFM is well established, the relationship between activity and FM in healthy children and adults is still in debate. ${ }^{22,32,33}$ Some studies have shown a positive relationship between activity-related energy expenditure and adiposity, mainly because of the increasing energy costs for weight-bearing activities. ${ }^{34}$ Other studies reported no effect of adiposity on PA when corrected for body weight or BMR. ${ }^{35}$ In the present study, the control group showed no effect of activity-related energy expenditure on adiposity (corrected for BMR), whereas in patients with PWS, adiposity was inversely related with PA. Because the data in the present study were obtained in a cross-sectional manner, it remains unclear whether reduced PA in patients with PWS causes an increase in FM or the higher level of FM restricts them from being physically active.

It has been speculated that, besides GHD and physical inactivity, puberty delay could also be responsible for the reduction in FFM. ${ }^{8}$ In the present study, the patients were matched for bone age and gender, resulting in a similar puberty development, ranging from pre- to postpubescent, as was confirmed by the sexual maturation stages of Tanner. ${ }^{25}$ In spite of the similarity in puberty development and sexual maturation, the reduction of FFM was still present and does not support puberty delay as a explanatory factor for this reduction.
The reduced lean body mass in patients with PWS resembles that of persons with GHD. ${ }^{36,37}$ In adults, GHD is associated with shrinking of the ICW compartment, possibly as a result of protein catabolism. ${ }^{10,38}$ The higher ECW/ICW ratio in the group with PWS seems to support the hypothesis of functional GHD. Adiposity, however, also increases the ECW compartment (plasma water, interstitial water [including lymph], and connective tissue water [including bone and cartilage]), as was demonstrated in healthy obese children. ${ }^{39,40}$ The strong relation of ECW to FM is thought to be one of the reasons why a high ratio of ECW/ICW is associated with cardiovascular diseases such as hypertension. ${ }^{41}$ Furthermore, it is known that ECW/ICW shows a gender-specific decrease during maturation ${ }^{42}$; therefore, multiple linear regression is needed to correct for the effect of adiposity and gender on ECW/ICW. The present results show that, even when corrected for adiposity, gender, and physiological maturation, ECW/ICW was higher in the group with PWS compared with the nonsyndromal obese control group. Possibly, this is explained by a combination of 2 separate effects, (1) increasing ECW caused by adiposity; and (2) decreased ICW as a result of diminished GH function, as is indicated by the positive correlation between IGF-I and ICW (Table III).

Although the fasting level of IGF-I cannot be used as the "gold standard" for $\mathrm{GH}$ function, IGF-I is known to be principally regulated by $\mathrm{GH}^{43}$ and proposed to be used as a marker for GH status in disturbed GH secretion. ${ }^{44,45}$ In healthy children, IGF-I changes with age, puberty development, and outdoor temperature, when short-term variations are mainly influenced by weight changes and illness. ${ }^{46}$ All of these factors were controlled for in the present study. Although IGF-I levels in patients with PWS have been reported to range from normal to subnormal, ${ }^{37,47,48}$ as was confirmed in the present study, it may still be possible, arguably, that the GH function is diminished because of a loss of sensitivity for GH metabolites.

It has been reported that adolescent patients with PWS may fracture their bones easily after minor trauma. ${ }^{49} \mathrm{~A}$ functional GHD in patients with PWS could be responsible for the specific reduction of bone mass in the limbs. The positive association between IGF-I and $\mathrm{BMD}_{\text {limbs }}$, adjusted for bone age and body weight, supports this relationship. Furthermore, the present data show an increased BMC in relation to FFM in the group with PWS, in combination with a tendency toward lower absolute measure of $\mathrm{BMC}$, especially in the limbs $(P=.051)$. This suggests that, on the level of the total body, there is a relatively larger deficit of muscle mass, whereas in the limbs, a relatively stronger reduction of bone mass is present. Brambilla et $\mathrm{al}^{8}{ }^{8}$ who measured bone mineralization in children and adults with PWS, found a significant difference in BMC of the total body and in the limbs, but those findings refer only to the older patients with PWS, whereas the BMC in relation to FFM was normal. We presume that the abnormalities of the somatotrophic and hypothalamic-pituitary-gonadal axis in PWS will have a stronger effect on bone metabolism after growth, leading to an increased risk for osteoporosis beginning from adolescence.

Increased levels of IGF-I and PA may have beneficial effects on adiposity and $\mathrm{ECW} / \mathrm{ICW}$, each via a different mode of 
action. IGF-I would lead to an increase in FFM, whereas PA decreases FM, in both cases decreasing the level of adiposity. Consequently, the decrease in FM would lead to a decrease in ECW/ICW. This reduction in ECW/ICW would also be achieved when ICW is increased as a result of increased levels of IGF-I. Furthermore, IGF-I may have an additional positive effect on $\mathrm{BMD}_{\text {limbs }}$. If a positive effect of PA on body composition exists in patients with PWS, it might lead to alternative intervention strategies that combine PA with hormonal therapy to prevent the development of obesity in patients with PWS.

We thank Drs L. M. G. Curfo and C. T. R. M. Schrander-Stumpel from the department of Clinical Genetics, the Dutch Prader-Willi Adsociation, the public bealth department of the Maastricht region, and, particularly, the chilJren and their parents for participating and making the study possible.

\section{RefERENCES}

1. Prader A, Labhart A, Willi H. Ein syndrom von adipositas, kleinwuchs, kryptorchismus, und oligophrenie nach myotonieartigem zustand in neugeborenenalter. Schweiz Med Wochenschr 1956;86:1260-1.

2. Glenn CC, Driscoll DJ, Yang TP, Nicholls RD. Genomic imprinting: potential function and mechanisms revealed by the Prader-Willi and Angelman syndromes. Mol Hum Reprod 1997;3:321-32.

3. Holm VA, Cassidy SZ, Butler MG, Hanchett JM, Greenswag LR, Whitman BY, et al. Prader-Willi syndrome: consensus diagnostic criteria. Pediatrics 1993;91:398-402.

4. Costeff H, Holm VA, Ruvalcaba R, Shaver J. Growth hormone secretion in Prader-Willi syndrome. Acta Paediatr Scand 1990;79:1059-62.

5. Angelo M, Castro-Magna M, Uv J, Rosenberg W. Growth hormone evaluation and treatment in Prader-Willi syndrome[abstract]. Pediatr Res 1991; 29:126A.

6. Kamel A, Margery V, Norstedt B, Thoren M, Lindgren A-N, Bronnegard $\mathrm{M}$, et al. Growth hormone $(\mathrm{GH})$ treatment up-regulates $\mathrm{GH}$ receptor mRNA levels in adipocytes from patients with
GH deficiency and Prader-Willi syndrome. Pediatr Res 1995;38:418-21.

7. Swaab DF. Prader-Willi syndrome and the hypothalamus. Acta Paediatr Suppl 1997;423:50-4

8. Brambilla P, Bosio L, Manzoni P, Pietrobelli A, Beccaria L, Chiumello G. Peculiar body composition in patients with Prader-Labhart-Willi syndrome. Am J Clin Nutr 1997;65:1369-74.

9. Lindgren AC, Hagenäs L, Müller J, Blichfeldt S, Rosenborg M, Brismar T, et al. Effect of growth hormone treatment on growth and body composition in Prader-Willi syndrome: a preliminary report. Acta Paediatr Suppl 1997;423:60-2.

10. Marken-Lichtenbelt WDv, Snel YEM, Brummer RJM, Koppeschaar HPF. Deuterium and bromide dilution, and bioimpedance spectrometry indepently show that growth hormone-deficient adults have an enlarged extracellular water compartment related to intracellular water. J Clin Endocrinol Metab 1997;82:907-11.

11. Davies PSW, Joughin C. Using stable isotopes to assess reduced physical activity of individuals with Prader-Willi syndrome. Am J Ment Retard 1993; 98:349-53.

12. Stunkard A, Pestka J. The physical activity of obese girls. Am J Dis Child 1962;103:116-21.

13. Gortmaker SL, Must A, Sobol AM, Peterson K, Colditz GA, Dietz WH. Television viewing as a cause of increased obesity among children in the United States, 1986-1990. Arch Ped Adol Med 1996;150:356-62.

14. Hill OJ, Trowbridge FL. Childhood obesity: future directions and research priorities. Pediatrics 1998;101:570-4.

15. Cox LA. The biology of bone maturation and ageing. Acta Paediatr Suppl 1997;423:107-8.

16. Tanner JM, Whitehouse RH, Marshall WA, Healy MJR, Goldstein H. Assessment of skeletal maturity and prediction of adult height (TW2 Method). London (UK): Academic Press; 1983.

17. Goran MI, Nagy TR, Gower BA, Mazariegos M, Solomons N, Hood V, et al. Influence of sex, seasonality, ethnicity, and geographic location on the components of total energy expenditure in young children: implications for energy requirements. Am J Clin Nutr 1998; 68:675-82.

18. Westerterp KR, Wouters L, MarkenLichtenbelt WDv. The Maastricht Protocol for the measurement of body composition and energy expenditure with labeled water. Obes Res 1995; 3:49-57.
19. van Mil EGAH, Westerterp KR, Gerver WJM, Curfs LMG, SchranderStumpel CTM, Kester ADM, et al. Energy expenditure at rest and during sleep in children with Prader-Willi syndrome is explained by body composition. Am J Clin Nutr 2000;71:752-6.

20. van Mil EG, Westerterp KR, Kester AD, Curfs LM, Gerver WJ, Schrander-Stumpel CT, et al. Activity related energy expenditure in children and adolescents with Prader-Willi syndrome. Int J Obes 2000;24:429-34.

21. Goran MI. Variation of total energy expenditure in humans. Obes Res 1995; 3:59-66.

22. Goran MI, Carpenter WH, McGloin A, Johnson R, Hardin JM, Weinsier RL. Energy expenditure in children of lean and obese parents. Am J Physiol 1995;268:E917-24.

23. Schoeller DA, Santen Ev, Petterson DW, Dietz W, Jaspan J, Klein PD. Total body water measurement in humans with $18 \mathrm{O}$ - and $2 \mathrm{H}$-labeled water. Am J Clin Nutr 1980;33:2686-93.

24. Boileau RA, Lohman TG, Slaughter MH, Ball TE, Going SB, Hendrix MK. Hydration of the fat-free body in children during maturation. Hum Biol 1984;56:651-66.

25. Tanner JM. Growth at adolescence. 2nd ed. London (UK): Blackwell Scientific Publications Ltd; 1962. p. 16-9.

26. Holm VA, Nugent JK. Growth in the Prader-Willi syndrome. Birth Defects 1982;18(No. 3B):93-100.

27. Butler MG, Meaney FJ. Standards for selected anthropometric measurements in Prader-Willi syndrome. Pediatrics 1991;88:853-60.

28. Westerterp KR, Meijer GAL, Kester ADM, Wouters L, Hoor FT. Fat-free mass as a function of fat mass and habitual activity level. Int J Sports Med 1992;13:163-6.

29. Miller ME, Cosgriff JM, Forbes GB. Bromide space determination using anion-exchange chromatography for measurement of bromide. Am J Clin Nutr 1989;50:168-71.

30. Schoeller DA, Levitsky LL, Bandini LG, Dietz WW, Walczak A. Energy expenditure and body composition in Prader-Willi syndrome. Metabolism 1988;37:115-20.

31. Lee PD, Hwu K, Henson H, Brown BT, Bricker JT, LeBlanc AD, et al. Body composition studies in PraderWilli syndrome: effects of growth hormone therapy. In: Human body composition, Vol. 60. Houston (TX): Plenum Press; 1993. p. 201-7. 
32. Salbe AD, Fontvieille AM, Harper IT, Ravussin E. Low levels of physical activity in 5-year-old children. J Pediatr 1997;131:423-9.

33. Goran MI, Reynolds KD, Lindquist $\mathrm{CH}$. Role of physical activity in the prevention of obesity in children. Int J Obes 1999;23(Suppl 3):S18-S33.

34. Prentice AM, Goldberg GR, Murgatroyd PR, Cole TJ. Physical activity and obesity: problems in correcting expenditure for body size. Int $J$ Obes 1996;20:688-91.

35. Bandini LG, Schoeller DA, Dietz WH. Energy expenditure in obese and nonobese adolescents. Pediatr Res 1990;27:198-203.

36. Davies PSW, Evans S, Broomhead S, Clough H, Day JME, Laidlaw A, et al. Effect of growth hormone on height, weight, and body composition in Prader-Willi syndrome. Arch Dis Child 1998;78:474-6.

37. Lindgren AC, Hagenas L, Muller J, Blichfeldt S, Rosenborg M, Brismar T, et al. Growth hormone treatment of children with Prader-Willi syndrome affects linear growth and body composition favourably. Acta Paediatr 1998;87:28-31.

38. Häusinger D, Roth E, Lang F, Gerok W. Cellular hydration state: an important determinant of protein catabolism in health and disease. Lancet 1993;341:1330-2.
39. Waki M, Kral JG, Mazariegos M, Wang J, Pierson RN, Heymsfield SB. Relative expansion of extracellular fluid in obese vs. nonobese women. Am J Physiol 1991;261:E199-E203.

40. Battistini N, Virgili F, Severi S, Brambilla P, Manzoni P, Beccaria L, et al. Relative expansion of extracellular water in obese vs. normal children. J Appl Physiol 1995;79:94-6.

41. Raison J, Achimastos A, Asmar R, Simon A, Safar M. Extracellular and interstitial fluid volume in obesity with and without associated systemic hypertension. Am J Cardiol 1986; 57:223-6.

42. Fomon SJ, Haschke F, Ziegler EE, Nelson SE. Body composition of reference children from birth to age 10 years. Am J Clin Nutr 1982;35:1169-75.

43. Blum WB, Albertsson-Wikland K, Rosberg S, Ranke MB. Serum levels of insuline-like growth factor (IGF-I) and IGF binding protein 3 reflect spontaneous growth hormone secretion. J Clin Endocrinol Metab 1993;76:1610-6.

44. Smith W, Nam TJ, Underwood LE, Busby GH, Celnicker A, Clemmons DR. Use of insuline-like growth factor-binding protein-2 (IGFBP-2), IGFBP-3, and IGF-I for assessing growth hormone status in short children. J Clin Endocrinol Metab 1993;77:1294-9.
45. Kriström B, Jansson C, Rosberg S, Albertsson-Wikland K. Growth respons to growth hormone $(\mathrm{GH})$ treatment relates to serum insuline-like growth factor-I (IGF-I) and IGF-binding protein-3 in short children with various GH secretion capacities. J Clin Endocrinol Metab 1997;82:2889-98.

46. Gelander L, Blum WF, Larsson L, Rosberg S, Albertsson-Wikland K. Monthly measurements of insuline-like growth factor I (IGF-I) and IGF-binding protein-3 in healthy prepubertal children: characterization and relationship with growth: the 1-year growth study. Pediatr Res 1999;45:377-83.

47. Cappa M, Grossi A, Borrelli P, Ghigo E, Bellone J, Benedetti S, et al. Growth hormone $(\mathrm{GH})$ response to combined pyridostigmine and GH-releasing hormone administration in patients with Prader-Labhart-Willi syndrome. Horm Res 1993;39:51-5.

48. Eiholzer U, Stutz K, Weinmann C, Torresani T, Molinari L, Prader A. Low insulin, IGF-I and IGFBP-3 levels in children with Prader-Labhart-Willi syndrome. Eur J Pediatr 1998;157:890-3.

49. Rubin K, Cassidy SB. Hypogonadism and osteoporosis. In: Greenswag LR, Alexander RC, editors. Management in Prader-Willi syndrome. New York (NY): Springer-Verlag; 1988. p. 23-33.

\section{BOUND VOLUMES AVAILABLE TO SUBSCRIBERS}

Bound volumes of the 2001 issues of The Journal of Pediatrics are available to subscribers (only) from the publisher, at a cost of $\$ 100.00$ for domestic, $\$ 125.19$ for Canadian, and $\$ 117.00$ for international subscribers, for Vol 138 (January-June) and Vol 139 (July-December), shipping charges included. Each bound volume contains subject and author indexes, and all advertising is removed. Copies are shipped within 60 days after publication of the last issue in the volume. The binding is durable buckram, with the Journal name, volume number, and year stamped in gold on the spine. Payment must accompany all orders. Contact Mosby, Subscription Customer Service, 6277 Sea Harbor Dr, Orlando, FL 32887; phone 800-654-2452 or 407 $345-4000$.

Subscriptions must be in force to qualify. Bound volumes are not available in place of a regular Journal subscription. 